\title{
Isolation and identification of Salmonella spp. in raw milk from dairy herds in Colombia
}

\section{Isolamento e identificação de Salmonella spp. no leite cru de rebanhos leiteiros na Colômbia}

\author{
Rubiela Castañeda-Salazar ${ }^{1}$ (D); Adriana Pulido-Villamarín ${ }^{1}$; Geraldine Lorena Ángel-Rodríguez ${ }^{1}$; \\ Camila Andrea Zafra-Alba ${ }^{1}$; Olimpo Oliver-Espinosa ${ }^{2}$
}

\footnotetext{
${ }^{1}$ Pontificia Universidad Javeriana, Facultad de Ciencias, Departamento de Microbiología, Unidad de Investigaciones Agropecuarias, Bogotá, Colombia

${ }^{2}$ Universidad Nacional de Colombia, Facultad de Medicina Veterinaria y Zootecnia, Departamento de Salud Animal, Bogotá, Colombia
}

\begin{abstract}
Salmonellosis is a foodborne disease (FBD) that affects public health and can cause death in people. Many outbreaks of Salmonellosis have been reported due to the contamination of raw milk and dairy products with the pathogen. To determine the prevalence of Salmonella spp. in milk samples from four dairy herds in the Sabana of Bogotá in 2017, 112 milk samples were taken directly from the mammary gland during milking. All milk samples were cultured and tested to isolate and identify Salmonella spp. using microbiological and molecular methods. Salmonella spp. prevalence of milk samples was found to be $20.5 \%(\mathrm{n}=23)$. The main Salmonella serovars isolated were S. Newport $(60.87 \%), S$. Typhimurium (17.4\%), S. Virchow, S. Bredeney, and S. Anatum (4.3\% each one of the serovars). However, it was not possible to determine the Salmonella serotype in two isolates. The prevalence of Salmonella spp. in milk has not been studied extensively in Colombia. The $20.5 \%$ in the prevalence might be due to fact that the sample was taken directly from the mammary gland allowing a better chance of isolation by avoiding the dilutional effect of mixed milk from different cows in the buckets. This also suggests that the infection of the udder could have occurred by hematogenous dissemination or by milking machine contamination. This study highlights the need to implement measures to prevent contamination and reduce the problem in the herds, which will result in milk and dairy products with high standards of innocuity and quality and decrease the risk of foodborne illness.
\end{abstract}

Keywords: Salmonellosis. Zoonosis. PCR.

\section{RESUMO}

A salmonelose é uma doença transmitida por alimentos que afeta a saúde pública e pode causar a morte de pessoas. Muitos surtos de salmonelose têm sido relatados devido à contaminação de leite cru e produtos lácteos com o patógeno. Para determinar a prevalência de Salmonella spp. em amostras de leite de quatro rebanhos leiteiros na Sabana de Bogotá em 2017, cento e doze amostras de leite foram colhidas diretamente da glândula mamária durante a ordenha. Todas as amostras de leite foram cultivadas para isolar e identificar Salmonella spp. usando métodos microbiológicos e moleculares. A prevalência de Salmonella spp. nas amostras de leite foi de 20,5\% $(\mathrm{n}=23)$. Os principais sorovares de Salmonella identificados foram $S$. Newport (60,87\%), S. Typhimurium (17,4\%), S. Virchow, S. Bredeney e $S$. Anatum $(4,3 \%$ cada um dos sorovares). No entanto, não foram determinados os sorovares de dois isolados. A prevalência de Salmonella spp. no leite ainda não foi extensivamente estudada na Colômbia. Os 20,5\% na prevalência podem ser devidos ao fato de a amostra ter sido colhida diretamente da glândula mamária, permitindo uma melhor chance de isolamento, evitando o efeito de diluição do leite misto de diferentes vacas nos baldes, o que pode indicar infecção do úbere pela disseminação hematogênica ou por contaminação da ordenhadeira. Este estudo destaca a necessidade da implementação de medidas destinadas a prevenir a contaminação e reduzir o problema nos rebanhos, resultando em leite e produtos lácteos com altos padrões de inocuidade e qualidade, diminuindo o risco de doenças de origem alimentar.

Palavras-chave: Salmonellosis. Zoonoses. PCR. 


\section{Correspondence to:}

Rubiela Castañeda-Salazar

Pontificia Universidad Javeriana, Facultad de Ciencias,

Departamento de Microbiología

Carrera $7^{\mathrm{a}}$ No. $40-62$

Bogotá, Colombia

E-mail: castaneda.r@javeriana.edu.co.

Received: July 24, 2020

Approved: February 12, 2021

How to cite: Castañeda-Salazar R, Pulido-Villamarín A, Ángel-Rodríguez GL, Zafra-Alba CA, Oliver-Espinosa O. Isolation and identification of Salmonella spp. in raw milk from dairy herds in Colombia. Braz J Vet Res Anim Sci. 2021;58: e172805. https://doi.org/10.11606/issn.16784456.bjvras.2021.172805

\section{Introduction}

Salmonella spp. is a zoonotic pathogen that affects different animal species such as reptiles, birds, and mammals. This pathogen causes salmonellosis, which is the most common foodborne disease reported, making it a worldwide public health problem (Cummings et al., 2009a; Center for Disease Control and Prevention, 2018). Salmonellosis affects humans causing gastrointestinal disease that can develop into bacteremia with systemic alterations. Also, it may cause death in children and immuno-compromised individuals (Scallan et al., 2011; Giaccone et al., 2012; Center for Disease Control and Prevention, 2018).

According to the Food and Agriculture Organization of the United Nations (FAO), and the Centers for Disease Control and Prevention (CDC), the foods commonly associated with outbreaks around the world are beef, chicken and pork meat, chicken eggs, non-pasteurized milk, milk products such as powder milk, cheese, ice creams, and butter made from raw milk (Food and Agriculture Organization of the United Nations, 2009; Center for Disease Control and Prevention, 2018; U.S. Food and Drug Administration, 2019). In Colombia, these same food products have been implicated in foodborne diseases, along with cheese, rice mixes, fish, and seafood, among others (Instituto Nacional de Salud, 2019a). Nevertheless, the specific pathogen in those food products was not determined. The CDC has also reported 263 outbreaks of salmonellosis associated with raw milk consumption between 2015 - 2017, sickened 4859 people, and caused 12 deaths (Center for Disease Control and Prevention, 2019). Other means of transmission of this pathogen to humans include direct contact with infected animals that are active shedders, contact with the environment these animals inhabit, the contamination of food crops by using contaminated animal manure as fertilizer, and water contamination with feces from animals shedding the microorganism, ingestion of contaminated food or water, or by contamination of food by infected food handlers (Durango et al., 2004; Sivapalasingam et al., 2004; Cummings et al., 2009a; Cummings et al., 2009b; Giaccone et al., 2012).

There are currently more than 2600 Salmonella serovars (Guibourdenche et al., 2010), of which S. Enteritidis and S. Typhimurium are the most common foodborne pathogens (European Food Safety Authority, 2007; Zumbado \& Romero, 2015). In 2019, the Colombian National Institute of Health reported Salmonella spp. as the etiological agent in 28 out of 229 foodborne disease outbreaks in which the etiology was determined. In 2020, Salmonella spp. and S. Paratyphi have been isolated in 2 out of 63 outbreaks (Instituto Nacional de Salud, 2019b; Instituto Nacional de Salud, 2020). However, the food implicated was not determined. The Salmonella serovars that more commonly affects cattle are $S$. Dublin, $S$. Typhimurium, and $S$. Enteritidis, according to reports from France, the United Kingdom, and the USA (De Buyser et al., 2001, Haeghebaert et al., 2003; Mercado et al., 2013; Kemal, 2014; Harvey et al., 2017).

Salmonellosis is a common entity in cattle. Its clinical picture involves diarrhea, dehydration, fever, anorexia, septicemia, and, in some cases, abortion. The severity of the disease depends on the virulence, pathogenicity, infective dose, immunological status, and age of the host. However, in several cases, it is a subclinical disease (McGuirk \& Peek, 2003; Cummings et al., 2009b; Costa et al., 2012; Kemal, 2014). The origin of the infection in a herd is commonly due to an animal that sheds the agent in the feces, but it also can take place by excretion in the milk from asymptomatic shedders (Radke et al., 2002; Claeys et al., 2013; Radostits et al., 2017; Holschbach \& Peek, 2018). This last mechanism has a greater zoonotic potential (Murinda et al., 2002; Cummings et al., 2009b), as the cattle affected by Salmonella spp. usually shed the bacteria. However, asymptomatic shedders, usually adult cattle, can shed the bacteria without ever being sick (Cummings et al., 2009a; Cummings et al., 2009b). The rate of Salmonella shedding in feces is commonly associated with the disease. In dairy cows herds with a $20 \%$ shedding, there is an association with the clinical entity, whereas, in herds with the shedding of 5\%, it is related to asymptomatic animals (McGuirk \& Peek, 2003). Thus, to prevent infection in a herd, it is paramount to separate healthy cattle from diseased ones, because the latter can shed more than $10^{14}$ bacteria per day and the infective dose 
is regarded to be of $10^{6}-10^{11}$ microorganisms (McGuirk \& Peek, 2003; Holschbach \& Peek, 2018).

The detection and identification of Salmonella spp. can be done using selective/differential culture media, metabolic profiles, serotyping, and, more accurately, by conventional PCR (Malorny et al., 2003; El-Baz et al., 2017; Holschbach \& Peek, 2018). When doing PCR to confirm the presence of Salmonella spp. different genic fragments have been used. Gene invA with $284 \mathrm{pb}$, which is also specific for Salmonella spp., has been used (Malorny et al., 2003; El-Baz et al., 2017). Edwards et al. (2002) and El-Sebay et al. (2017) have shown that all of the SP1 loci, in which invA genes are contained, share almost the same identity of the whole genomes in different serotypes (varying between 97.7 and $98.6 \%$ similarities). Once the presence of Salmonella spp. is determined by PCR, then the identification of serovars can be done by DNA sequencing and analysis of the sequences using BLASTn (Holschbach \& Peek, 2018).

Since Salmonella spp. is shed in cow's milk and the consumption of raw milk and its dairy products have been identified as one of the most important routes of Salmonella infection in human beings (Oliver et al., 2005; Claeys et al., 2013; Lucey, 2015; Radostits et al., 2017; Holschbach \& Peek, 2018), and there are no studies determining Salmonella spp. shedding in milk from samples taken directly from the udder in Colombia, the main objectives of this study were to determine the prevalence of Salmonella spp. in milk samples obtained directly from the udder, to identify the present serotypes in four dairy herds, and to precisely identify the infected individuals.

\section{Materials and methods}

\section{Study population}

The sampling was done in four dairy herds in different locations in the Sabana of Bogotá. Each herd had a different number of animals and different breeds (Table 1). The inclusion criteria included that the farm owner accepted voluntarily to participate in the study, the cows were in lactation, and had no antibiotic treatment within one month before sampling.

\section{Sampling}

After disinfection with iodine or sulfonic acid, and fore stripping of each teat, a pool of $50 \mathrm{~mL}$ of milk from all quarters of each animal were collected in sterile falcon tubes that were labeled with the information of each animal. Sampling was done by the farm veterinarian following the biosecurity measures (udder disinfection, use of sterile
Table 1 - Herd identification, number of samples, and bovine breeds used for investigating the presence of Salmonella spp. in milk samples of dairy herds from Sabana of Bogotá, Colombia. Samples collected in 2017

\begin{tabular}{cccc}
\hline Herd & $\mathbf{N}^{\circ}$ animals (samples) & Breed & Location \\
\hline 1 & 16 & Normande & Bogotá \\
2 & 64 & Holstein & Madrid \\
3 & 16 & Normande - Gyr & Mosquera \\
4 & 16 & Holstein & Chía \\
Total & $\mathbf{1 1 2}$ & & \\
\hline
\end{tabular}

gloves, and discard the first squirt of milk) indicated by the researchers. Once the samples were collected, they were refrigerated and transported within $6 \mathrm{~h}$ of collection to the microbiology laboratory at the Pontificia Universidad Javeriana, where they were processed.

\section{Isolation and microbiological identification}

All samples were handled according to the Colombian technical standard NTC 4574: Food microbiology, animal food microbiology, and Oxoid Salmonella Precis ${ }^{\circledast}$ methodology.

For non-selective sample pre-enrichment, $25 \mathrm{~mL}$ of the milk sample were added to $225 \mathrm{~mL}$ of sterile peptone water and were incubated at $37^{\circ} \mathrm{C}$ for $18-24 \mathrm{~h}$. From this preenriched sample, $100 \mu \mathrm{L}$ were added to $10 \mathrm{~mL}$ of tetrathionate selective enrichment broth and then incubated at $42{ }^{\circ} \mathrm{C}$ for $24 \mathrm{~h}$ (Icontec, 2007). Afterward, samples from the broth were plated on the selective and differentiating agar media Hektoen and agar XLT4 and incubated at $37^{\circ} \mathrm{C}$ for $18-24 \mathrm{~h}$.

Following the Oxoid Salmonella Precis methodology, $25 \mathrm{~mL}$ of milk were added to $225 \mathrm{~mL}$ of One broth ${ }^{\circledR}$ incubated at $42{ }^{\circ} \mathrm{C}$ for $24 \mathrm{~h}$, followed by plating on agar Brilliance Salmonella ${ }^{\circ}$ and incubated at $37^{\circ} \mathrm{C}$ for $18-24 \mathrm{~h}$.

After the incubation period, all the colonies morphologically similar to Salmonella spp. were selected and conventional biochemical tests such as SIM, TSI, and urea were performed. To perform these tests, the cultures were incubated at $37^{\circ} \mathrm{C}$ for $18 \mathrm{~h}$ (Winn et al., 2008) and confirmed using the Rapid $\mathrm{One}^{\circledast}$ galleries. All the confirming microbiology and molecular procedures involved the use of the reference strains S. Typhimurium (ATCC 14028) and S. Enteritidis (ATCC 13076) for quality control procedures.

\section{Molecular identification}

All the Salmonella-compatible isolates underwent molecular identification using a PCR kit (CorpoGen BM-00007) that contains a lysis buffer for bacterial DNA extraction and a master mix of PCR to amplify a fragment of $284 \mathrm{pb}$ that is specific for Salmonella spp. invA gene. The isolated colonies were suspended again in nutritional broth and incubated at $37^{\circ} \mathrm{C} / 24 \mathrm{~h}$ for DNA extraction, $50 \mu \mathrm{L}$ of 
the broth was added to a microtube with $200 \mu \mathrm{L}$ of the lysis buffer. This was mixed and incubated for $10 \mathrm{~min}$ at $92^{\circ} \mathrm{C}$ on a heating dry block. Afterward, it was centrifuged at $12.492 \mathrm{~g}$ for $5 \mathrm{~min}$. The amplification was done by adding $2 \mu \mathrm{L}$ of extracted DNA to the PCR tubes following the test's insert instructions. The conditions of the reaction were an initial denaturation cycle at $95^{\circ} \mathrm{C}$ for $1 \mathrm{~min}, 35$ cycles of denaturation at $95^{\circ} \mathrm{C}$ for $30 \mathrm{sec}$, annealing at $66^{\circ} \mathrm{C}$ for 30 sec and extension at $72{ }^{\circ} \mathrm{C}$ for $30 \mathrm{sec}$, and an extension final cycle at $72{ }^{\circ} \mathrm{C}$ for $4 \mathrm{~min}$. The detection of Salmonella spp. was confirmed by determining the $284 \mathrm{bp}$ fragment using $1.5 \%$ agarose gel electrophoresis stained with $\mathrm{SYBR}^{\circ}$ safe (Invitrogen).

The identification of the serovars was done by DNA sequencing and analyzed using BLASTn (Identities \% 97 - 99\%; E-value 0.0), as follows: the PCR products were placed into $0.2 \mathrm{ml}$ Eppendorf tubes, the first 17 samples were sent to Macrogen and the other 6 to the microbiology laboratory of the University of the Andes to be sequenced, all the samples were sequenced by the Sanger's methodology, and the obtained sequences were analyzed by the BLAST web tool of the Gene Bank (NCBI).

\section{Results}

The study showed a 20.5\% prevalence of Salmonella spp. $(\mathrm{n}=23 / 112)$ in the herds studied. Herds 1 ( 1 out of 16$), 2$ (16 out of 64 ), and 3 ( 6 out of 16 ) had a prevalence of $0.89 \%$, $14.28 \%$, and $5.35 \%$, respectively. All animals from herd 4 were negative for Salmonella spp.

All the samples microbiologically identified as Salmonella spp. $(n=23 / 112)$ were confirmed using the commercial PCR kit (CorpoGen ${ }^{\circledR}$ BM-00007) that allows visualization of the expected fragment of $284 \mathrm{bp}$ specific for Salmonella's gen invA in an electrophoresis gel.

The sequencing results showed that $60.87 \%$ of the isolates were identified as Salmonella Newport, 17.4\% as S. Typhimurium, $8.7 \%$ as Salmonella spp., and other serovar were also identified as $S$. Virchow, $S$. Bredeney, and $S$. Anatum in $4.34 \%$ each (some of the sequences obtained and the Blast results are shown in Table 2). Regarding the isolated serovars, there were several serovars in herds 2 and 3 as shown in Table 3, a single serovar was identified per animal.

\section{Discussion}

This study found an overall Salmonella spp. prevalence of $20.5 \%$ in animals. These findings are different from the ones already reported by Patiño (2012) in a study that involved the determination of this microorganism in different regions of Colombia. In that study, the samples were taken from transporting milk buckets and the prevalence found was $0.83 \%$, the specific prevalence in the studied regions were Cesar Valley 0\%, 0.5\% in savannahs of Cordoba and Sucre, and $0.33 \%$ in the high and low Magdalena river. Along with the results by Patiño (2012), in the USA and Australia, the observed prevalence in raw milk have ranged between $0 \%-11 \%$ (Murinda et al., 2002; Karns et al., 2005; Jayarao et al., 2006; D'Amico et al., 2008; Claeys et al., 2013; McAuley et al., 2014; Lucey, 2015). A prevalence of $<1 \%$ has also been reported in Europe from a bulk tank (De Reu et al., 2004; Claeys et al., 2013). The difference in prevalence with the previously cited studies could be attributed to the sampling method. In those studies, the samples were taken from bulk tanks and not directly from the udder, a method that may cause a dilutional or temperature effect that could reduce the rate of isolation. It also could be that in our study only four farms were sampled and/or the herds had a high rate of infection and the biosecurity in the farms was limited. However, it is similar to a study in the city of Tandojam (Pakistan) that reported a $15.3 \%$ prevalence in raw milk in different localities of the city (Baloch et al., 2015).

The observed differences in the prevalence among herds $(0.89 \%, 14.3 \%, 5.4 \%$, and $0 \%)$ may be due to several factors that include the management and inadequate hygienic conditions of the herds, milking parlor, mammary gland, milkers, and milk handlers, and in the animals. The possible contamination of the drinking water or the food with the pathogen, the presence of asymptomatic shedders, among others, may also play important roles in the presence and propagation of the microorganism within the herds as has been found by several researchers (Vanselow et al., 2007; Carrique-Mas et al., 2010; Jones, 2011; Claeys et al., 2013; Kemal, 2014; Pandey et al., 2014; Martínez et al., 2015; Tarazi \& Abo-Shehada, 2015; Delgado et al., 2016; Sarkar, 2016). It has been determined that mechanical milking generates a greater likelihood of milk contamination with bacteria such as S. Enteritidis, E. coli, and L. monocytogenes, among others, due to the contamination of the system duct filters in the milking machines (Oliver et al., 2005; Van Kessel et al., 2011). Since all the studied herds use milking machines, it is important to periodically evaluate the milking equipment to determine its role in milk contamination and/or the role in the infection of cows with Salmonella spp. Also, given that the samples were taken directly from the udder which had been thoroughly disinfected, and there were no signs of infection in the mammary gland, it is likely that the positive cows were asymptomatic carriers and shedders of the microorganism in the milk (Radostits et al., 2017; Holschbach \& Peek, 2018). 


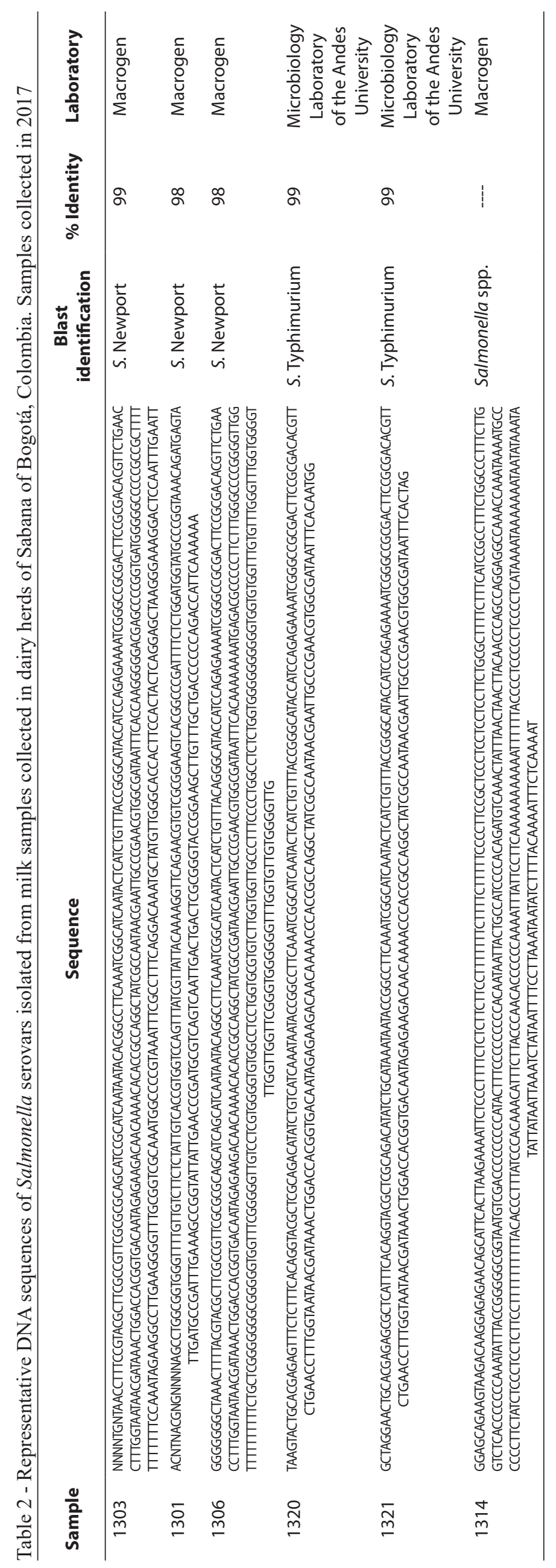


Table 3 - Herd identification, number of positive animals according to the herd, and serovars identified in milk samples of each dairy herd from Sabana of Bogotá, Colombia. Samples collected in 2017

\begin{tabular}{ccc}
\hline Herd & Positive animals & Serovar identified \\
\hline 1 & 1 & S. Newport \\
2 & 16 & $\begin{array}{c}\text { S. Newport, S. Bredeney, S. Virchow, } \\
\text { S. Typhimurium, S. Anatum, } \\
\text { Salmonella spp. }\end{array}$ \\
3 & 6 & S. Newport, S. Typhimurium \\
4 & 0 & \\
\hline
\end{tabular}

The serotypes identified included $S$. Newport, $S$. Typhimurium, $S$. Virchow, $S$. Bredeney, and $S$. Anatum that belong to the Salmonella groups B, C, and E. These findings are similar to the findings reported by Peek et al. (2017) who found, besides $S$. Dublin, other serovars that belong to the groups mentioned previously in milk samples and/or dairy products (Van Kessel et al., 2013; El-Baz et al., 2017; Peek et al., 2017). They indicated that those findings were either associated with septicemic processes with dissemination to the mammary gland, milking machine contamination, or the contamination of the milk with feces (Peek et al., 2017). In the current study, we consider that the infection of the udder could have occurred by hematogenous dissemination or by milking machine contamination.

In the present study, $S$. Newport was the serovar with the highest prevalence. This finding is similar to one study in the USA that determined $S$. Montevideo and $S$. Newport as the most commonly present in milk, although $S$. Muenster, S. Dublin, S. Meleagridis, and S. Cerro were also found in lower proportions from bulk tanks samples. But the serovar identification in this former study was done using serology (Van Kessel et al., 2003). On the other hand, Van Kessel et al. (2004) and Van Kessel et al. (2011) detected the presence of $S$. Cerro in $9 \%$ and $25 \%$, S. Anatum in $4.54 \%$ and $16.6 \%, S$. Montevideo in $31.81 \%$ and $16.6 \%$, S. Newport in $18.18 \%$ and $0 \%$, respectively, in the cultured samples in the USA (Van Kessel et al., 2004; Van Kessel et al., 2011). Additionally, studies in Egypt found mainly $S$. Enteritidis $6-12 \%, S$. Typhimurium in $2-8 \%, S$. Heidelberg in $8 \%$, and $S$. Infantis in $2-4 \%$ of the milk samples, findings that are in partial concordance with the present study. However, Salmonella identification in the previously cited reports was done in milk from bulk tanks (El-Baz et al., 2017; Omar et al., 2018). Prevalence determined in a study in India, using PCR on milk samples from different stores, was $5.6 \%$, in which the leading isolates were $S$. Typhimurium and $S$. Newport, results that are similar to our findings (Kaushik et al., 2014).

According to research that was done by Cummings et al. (2009b), the predominant serovars isolated from feces were
$S$. Newport and $S$. Typhimurium (including the Copenhagen strain) in $41 \%$ and $19.1 \%$, respectively (Cummings et al., $2009 b)$. This may suggest likely contamination and/or infection of the udder with bacteria from the feces of asymptomatic shedders. This possible route of infection demands more research.

Given that different studies have identified Salmonella spp. as one of the main pathogenic agents associated with foodborne diseases in humans along with either the risk of raw milk consumption or dairy products from raw milk (Murinda et al., 2002; Mazurek et al., 2004; Van Kessel et al., 2004; Karns et al., 2005; Oliver et al., 2005; Instituto Nacional de Salud, 2011; Van Kessel et al., 2013; Omar et al., 2018), it underscores the need to establish high hygienic standards throughout the milk production chain in Colombia (Sivapalasingam et al., 2004; Karns et al., 2005; Van Kessel et al., 2011).

\section{Conclusion}

This is the first study on determining the presence of Salmonella spp. and its serovars in milk obtained directly from the udder in Colombia. It also confirms that Salmonella can be shed through milk. Study limitations include the number of herds and the purposive sampling. This study should further the research using bigger samples and more farms to more accurately determine the actual prevalence and the involved serotypes isolated directly from the udder. Also, this study highlights the need to implement measures to prevent contamination and reduce the problem in the herds, which will result in milk and dairy products with high standards of innocuity and quality and decrease the risk of foodborne illness.

\section{Conflict of Interest}

The authors declare that they do not have any conflict of interest.

\section{Ethics Statement}

The authors declare that the research project was approved by the Ethics committee of the Faculty of Science (resolution $\mathrm{N}^{\circ} 14$ de 2016) and by the animal care committee - CICUAL (document C-069-16) of the Pontificia Javeriana University. This approval was done under resolutions 008430/1993 and 2378/2008 of the Republic of Colombia.

\section{Acknowledgements}

To the Pontificia Javeriana University for funding the study through an internal research Grant. ID Project: 007609. To the DVMs that helped with sample collection and the farm owners that accepted to participate in the study. 


\section{References}

Baloch AR, Sattar BA, Baloch AB, Faraz SS, Arian MA, Soomro RN, Otho SA, Zakria HM, Abbasi IHR, Baloch AM, Saeed M, Kalhoro SA. A cross-sectional study on the prevalence of Salmonella in Raw Milk in Tandojam and Surrounding Areas, Pakistan. J Anim Pro Adv. 2015;5(2):612-6. http:// dx.doi.org/10.5455/japa.20150208013729.

Carrique-Mas JJ, Willmington JA, Papadopoulou C, Watson EN, Davies RH. Salmonella infection in cattle in Great Britain, 2003 to 2008. Vet Rec. 2010;167(15):560-5. http:// dx.doi.org/10.1136/vr.c4943. PMid:21257417.

Center for Disease Control and Prevention - CDC [Internet]. National Outbreak Reporting System (NORS). Atlanta, GA: CDC; 2019 [cited 2019 Oct 10]. Available from: https:// wwwn.cdc.gov/norsdashboard/.

Center for Disease Control and Prevention - CDC [Internet]. Salmonella. Atlanta, GA: CDC; 2018 [Accessed 2019 Sept 7]. Available from: http://www.cdc.gov/salmonella/general/ technical.html.

Claeys WL, Cardoen S, Daube G, De Block J, Dewettinck K, Dierick K, De Zutter L, Huyghebaert A, Imberechts H, Thiange P, Vandenplas Y, Herman L. Raw or heated cow milk consumption: review of risks and benefits. Food Control. 2013;31(1):251-62. http://dx.doi.org/10.1016/j. foodcont.2012.09.035.

Costa LF, Paixão TA, Tsolis RM, Bäumler AJ, Santos RL. Salmonellosis in cattle: advantages of being an experimental model. Res Vet Sci. 2012;93(1):1-6. http://dx.doi.org/10.1016/j. rvsc.2012.03.002. PMid:22483382.

Cummings KJ, Warnick LD, Alexander KA, Cripps CJ, Gröhn YT, James KL, McDonough PL, Reed KE. The duration of fecal Salmonella shedding following clinical disease among dairy cattle in the northeastern USA. Prev Vet Med. 2009a;92(1-2):134-9. http://dx.doi.org/10.1016/j. prevetmed.2009.07.002. PMid:19665243.

Cummings KJ, Warnick LD, Alexander KA, Cripps CJ, Gröhn YT, McDonough PL, Nydam DV, Reed KE. The incidence of salmonellosis among dairy herds in the Northeastern United States. J Dairy Sci. 2009b;92(8):3766-74. http:// dx.doi.org/10.3168/jds.2009-2093. PMid:19620658.

D’Amico DJ, Groves E, Donnelly CW. Low incidence of foodborne pathogens of concern in raw milk utilized for farmstead cheese production. J Food Prot. 2008;71(8):1580-
9. http://dx.doi.org/10.4315/0362-028X-71.8.1580. PMid:18724751.

De Buyser ML, Dufour B, Maire M, Lafarge V. Implication of milk and milk products in food-borne diseases in France and in different industrialized countries. Int J Food Microbiol. 2001;67(1-2):1-17. http://dx.doi.org/10.1016/ S0168-1605(01)00443-3. PMid:11482557.

Delgado A, González H, Rodríguez R, Véliz G. Prevalencia de Escherichia coli y Salmonella spp. en becerras Holstein con diarrea en la Comarca Lagunera, México. Agrofaz. 2016;16(1):57-64.

De Reu K, Grijspeerdt K, Herman L. A Belgian survey of hygiene indicator bacteria and pathogenic bacteria in raw milk and direct marketing of raw milk farm products. J Food Saf. 2004;24(1):17-36. http://dx.doi. org/10.1111/j.1745-4565.2004.tb00373.x.

Durango J, Arrieta G, Mattar S. Presencia de Salmonella spp. en un área del caribe colombiano: un riesgo para la salud pública. Biomedica. 2004;24(1):89-96. http://dx.doi. org/10.7705/biomedica.v24i1.1252. PMid:15239605.

Edwards R, Olsen E, Maloy S. Comparative genomics of closely related salmonellae. Trends Microbiol. 2002;10(2):949. http://dx.doi.org/10.1016/S0966-842X(01)02293-4. PMid:11827811.

El-Baz AH, El-Sherbini M, Abdelkhalek A, Al-Ashmawy MA. Prevalence and molecular characterization of Salmonella serovars in milk and cheese in Mansoura city, Egypt. J Adv Vet Anim Res. 2017;4(1):45-51. http://dx.doi.org/10.5455/ javar.2017.d189.

El-Sebay NA, Shady HMA, El-Zeedy SAE-R, Samy AA. InvA gene sequencing of Salmonella Typhimurium isolated from Egyptian poultry. Asian J. Sci. Res. 2017;10(3):194202. http://dx.doi.org/10.3923/ajsr.2017.194.202.

European Food Safety Authority - EFSA. The Community Summary Report on Trends and Sources of Zoonoses, Zoonotic Agents, Antimicrobial Resistance Foodborne Outbreaks in the European Union in 2006. Efsa J [Internet]. 2007 Dec [Accessed 2019 May 27];130:3-352. Available from: https://www.efsa.europa.eu/en/efsajournal/pub/rn-130.

Food and Agriculture Organization of the United Nations FAO [Internet]. Salmonella and Campylobacter in chicken 
meat: Meeting report. Geneva: FAO; 2009 [Accessed 2019 Nov 12]. Available from: http://www.fao.org/3/a-i1133e.pdf.

Giaccone V, Catellani P, Alberghini L. Food as cause of human salmonellosis. In: Mahmoud SM. Salmonella - A dangerous foodborne pathogen. Croatia: InTech open, Rijeka; 2012. p. 47-72. http://dx.doi.org/10.5772/30474.

Guibourdenche M, Roggentin P, Mikoleit M, Fields PI, Bockemühl J, Grimont P, Weill FX. Supplement 2003 - 2007 (No. 47) to the White-Kauffmann-LeMinor scheme. Res Microbiol. 2010;161(1):26-9. http://dx.doi.org/10.1016/j. resmic.2009.10.002. PMid:19840847.

Haeghebaert S, Sulem P, Deroudille L, Vanneroy-Adenot E, Bagnis O, Bouvet P, Espie E. Two outbreaks of Salmonella Enteritidis phage type 8 linked to the consumption of Cantal cheese made with raw milk, France, 2001. Euro Surveill. 2003;8(7-8):151-6.

Harvey RR, Friedman CR, Crim SM, Judd M, Barrett KA, Tolar B, Folster JP, Griffin PM, Brown AC. Epidemiology of Salmonella enterica Serotype Dublin Infections among Humans, United States, 1968-2013. Emerg Infect Dis. 2017;23(9):1493-501. http://dx.doi.org/10.3201/eid2309.170136. PMid:28820133.

Holschbach CL, Peek SF. Salmonella in dairy cattle. Vet Clin North Am Food Anim Pract. 2018;34(1):133-54. http:// dx.doi.org/10.1016/j.cvfa.2017.10.005. PMid:29224803.

Icontec. Microbiología de alimentos y alimentos para animales. Guía general sobre métodos para la detección de Salmonella. Norma Técnica Colombiana. 2007;4574:1-33.

Instituto Nacional de Salud. Enfermedades transmitidas por alimentos [Internet]. Colombia; 2020 [cited $2020 \mathrm{Nov}$ 12]. Available from: https://www.ins.gov.co/buscadoreventos/Informesdeevento/ENFERMEDADES\%20 TRANSMITIDAS\%20POR\%20ALIMENTOS\%20PE\%20 IX\%202020.pdf.

Instituto Nacional de Salud. Enfermedades transmitidas por alimentos [Internet]. Colombia; 2019a [cited 2020 Nov. 12]. Available from: https://www.ins.gov.co/buscador-eventos/ Informesdeevento/ENFERMEDAD\%20TRANSMITIDA\%20 POR\%20ALIMENTOS\%20SEMESTRE\%20I\%202019.pdf.

Instituto Nacional de Salud. Enfermedades transmitidas por alimentos [Internet]. Colombia; 2019b [cited 2020 Nov 12]. Available from: https://www.ins.gov.co/buscador-eventos/
Informesdeevento/ENFERMEDAD\%20TRANSMITIDA\%20 POR\%20ALIMENTOS\%20PE\%20XIII\%202019.pdf.

Instituto Nacional de Salud. Identificación de riesgos biológicos asociados al consumo de leche cruda bovina en Colombia [Internet]. Colombia; 2011 [cited 2019 Nov 18]. Available from: https://www.minsalud.gov.co/sites/ rid/Lists/BibliotecaDigital/RIDE/IA/INS/Er-peligrosbiologicos-en-leche.pdf.

Jayarao BM, Donaldson C, Straley A, Sawant A, Hegde N, Brown J. A survey of foodborne pathogens in bulk tank milk and raw milk consumption among farm families in Pennsylvania. J Dairy Sci. 2006;89(7):2451-8. http://dx.doi. org/10.3168/jds.S0022-0302(06)72318-9. PMid:16772561.

Jones FT. A review of practical Salmonella control measures in animal feed. J Appl Poult Res. 2011;20(1):102-13. http:// dx.doi.org/10.3382/japr.2010-00281.

Karns JS, Van Kessel JS, McCluskey BJ, Perdue ML. Prevalence of Salmonella enterica in bulk tank from US dairies as determined by Polimerase Chain Reaction. J Dairy Sci. 2005;88(10):3475-9. http://dx.doi.org/10.3168/ jds.S0022-0302(05)73031-9. PMid:16162520.

Kaushik P, Anjay, Kumari S, Bharti SK, Dayal S. Isolation and prevalence of Salmonella from chicken meat and cattle milk collected from local markets of Patna, India. Vet World. 2014;7(2):62-5. http://dx.doi.org/10.14202/ vetworld.2014.62-65.

Kemal J. A review on the public health importance of bovine salmonellosis. J Vet Sci Technol. 2014;5(02):175-82. http:// dx.doi.org/10.4172/2157-7579.1000175.

Lucey JA. Raw Milk Consumption: risks and Benefits. Nutr Today. 2015;50(4):189-93. http://dx.doi.org/10.1097/ NT.0000000000000108. PMid:27340300.

Malorny B, Hoofar J, Bunge C, Helmuth R. Multicenter validation of the Analytical Accuracy of Salmonella PCR: towards in an International Standard. Appl Environ Microbiol. 2003;69:290-6.

Martínez A, Villoch A, Ribot A, Montes de Oca N, Riverón Y, Ponce P. Calidad e inocuidad en la leche cruda de una cadena de producción de una provincia occidental de Cuba. Rev Salud Anim. 2015;37(2):79-85.

Mazurek J, Salehi E, Propes D, Holt J, Bannerman T, Nicholson LM, Bundesen M, Duffy R, Moolenaar RI. 
A Multistate Outbreak of Salmonella enterica Serotype Typhimurium Infection Linked to Raw Milk Consumption: Ohio, 2003. J Food Prot. 2004;67(10):2165-70. http://dx.doi. org/10.4315/0362-028X-67.10.2165. PMid:15508625.

McAuley CM, McMillan K, Moore SC, Fegan N, Fox EM. Prevalence and characterization of foodborne pathogens from Australian dairy farm environments. J Dairy Sci. 2014;97(12):7402-12. http://dx.doi.org/10.3168/jds.20148735. PMid:25282417.

McGuirk SM, Peek S. Salmonellosis in cattle: a review. In: Proceedings of the 36th Annual Conference of the American Association of Bovine Practitioners; 2003; Columbus, OH, USA; 2003 Sept 15-17. p. 144-152.

Mercado M, González V, Rodríguez D, Carrascal A. Perfil sanitario nacional de leche cruda para consumo humano directo [Internet]. Colombia: Ministerio de Salud; 2013 [cited 2019 Nov 23]. Available from: https://www.minsalud. gov.co/sites/rid/Lists/BibliotecaDigital/RIDE/VS/PP/SNA/ Perfil-sanitario-nacional-leche-cruda.pdf.

Murinda SE, Nguyen LT, Ivey SJ, Gillespie BE, Almeida RA, Draughon FA, Oliver SP. Molecular characterization of Salmonella spp. isolated from bulk tank milk and cull dairy cow fecal samples. J Food Prot. 2002;65(7):1100-5. http:// dx.doi.org/10.4315/0362-028X-65.7.1100. PMid:12117241.

Oliver SP, Jayarao BM, Almeida RA. Foodborne pathogens in milk and the dairy farm environment: food safety and public health implications. Foodborne Pathog Dis. 2005;2(2):115-29. http://dx.doi.org/10.1089/fpd.2005.2.115. PMid:15992306.

Omar D, Al-Ashmawy M, Ramadan H, El-Sherbiny M. Occurrence and PCR identification of Salmonella spp. from milk and dairy products in Mansoura, Egypt. Int Food Res J. 2018;25(1):446-52.

Pandey N, Kumari A, Varma AK, Sahu S, Akbar MA. Impact of applying hygienic practices at farm on bacteriological quality of raw milk. Vet World. 2014;7(9):754-8. http:// dx.doi.org/10.14202/vetworld.2014.754-758.

Patiño R. Detección de Salmonella spp., Escherichia coli O157:H7 y Listeria monocytogenes, en muestras de leche bovina del sistema de producción doble propósito colombiano, Bogotá, Colombia [thesis]. Bogotá: Pontificia Universidad Javeriana, Facultad de Ciencias, Departamento de Microbiología; 2012. [cited 2019 Sept 12]. Available from: https://repository.javeriana.edu.co/bitstream/
handle/10554/3424/PatinoBurbanoRocioEsperanza2012. pdf? sequence $=1$ \&isAllowed $=\mathrm{y}$.

Peek SF, McGuirk SM, Sweeney RW, Cummings KJ. Infectious diseases of the gastrointestinal tract. In: Peek SF, Divers TJ. Diseases of dairy cattle. 3rd ed. St. Louis, MO: Elsevier; 2017. p. 304-311.

Radke BR, McFall M, Radostits SM. Salmonella Muenster infection in a dairy herd. Can Vet J. 2002;43(6):443-56. PMid:12058570.

Radostits OM, Gay CC, Hinchcliff KW, Constable PD. Veterinary medicine. 10th ed. Philadelphia: SaundersElsevier; 2017.

Sarkar S. Microbiological safety concerns of raw milk. J Food Nutr Diet. 2016;1(2):105. http://dx.doi.org/10.19104/ jfnd.2016.105.

Scallan E, Hoekstra RM, Angulo FJ, Tauxe RV, Widdowson MA, Roy SL, Jones JL, Griffin PM. Foodborne illness acquired in the United States: major pathogens. Emerg Infect Dis. 2011;17(1):7-15. http://dx.doi.org/10.3201/ eid1701.P11101. PMid:21192848.

Sivapalasingam S, Friedman CR, Cohen L, Tauxe RV. Fresh produce: a growing cause of outbreaks of foodborne illness in the United States, 1973 through 1997. J Food Prot. 2004;67(10):2342-53. http://dx.doi.org/10.4315/0362028X-67.10.2342. PMid:15508656.

Tarazi H, Abo-Shehada N. Herd-and individual-level prevalences of and risk factors for Salmonella spp. fecal shedding in dairy farms in Al-Dhulail Valley, Jordan. Trop Anim Health Prod. 2015;47(7):1241-8. http://dx.doi. org/10.1007/s11250-015-0854-z. PMid:26065698.

U.S. Food and Drug Administration. The dangers of raw milk: Unpasteurized milk can pose a serious health risk. FDA; 2019 [cited 2019 Oct 23]. Available from: http://www. fda.gov/Food/ResourcesForYou/consumers/ucm079516.htm.

Van Kessel JS, Sonnier J, Zhao S, Karns JS. Antimicrobial Resistance of Salmonella enterica Isolates from Bulk Tank Milk and Milk Filters in the United States. J Food Prot. 2013;76(1):18-25. http://dx.doi.org/10.4315/0362-028X. JFP-12-263. PMid:23317852.

Van Kessel JS, Karns JS, Lombard J, Kopral C. Prevalence of Salmonella enterica, Listeria monocytogenes, and Escherichia coli virulence factors in bulk tank milk and in-line filters 
from U.S. dairies. J Food Prot. 2011;74(5):759-68. http:// dx.doi.org/10.4315/0362-028X.JFP-10-423. PMid:21549046.

Van Kessel JS, Karns JS, Gorski L, McCluskey BJ, Perdue ML. Prevalence of Salmonella, Listeria monocytogenes, and fecal coliforms in bulk tank milk on US Dairies. J Dairy Sci. 2004;87(9):2822-30. http://dx.doi.org/10.3168/jds. S0022-0302(04)73410-4. PMid:15375040.

Van Kessel JS, Karns JS, Perdue ML. Using a portable realtime PCR assay to detect Salmonella in Raw Milk. J Food Prot. 2003;66(10):1762-7. http://dx.doi.org/10.4315/0362028X-66.10.1762. PMid:14572210.

Vanselow A, Hornitzky A, Walker H, Eamens J, Bailey D, Gill A, Coates K, Corney B, Cronin P, Renilson S. Salmonella and on-farm risk factors in healthy slaughter age cattle and sheep in eastern Australia. Aust Vet J. 2007;85(12):498-
502. http://dx.doi.org/10.1111/j.1751-0813.2007.00233.x. PMid:18042157.

Winn WC, Allen SD, Janda WM, Koneman EW, Procop GW, Schrenckenberger PC, Woods GL. Diagnóstico Microbiológico. 6th ed. Buenos Aires, Argentina: Editorial Médica Panamericana; 2008.

Zumbado Gutiérrez L, Romero Zuñiga JJ. Conceptos sobre inocuidad en la producción primaria de la leche. Rev Ciencias Veterinarias. 2015;33(2):51-66. http://dx.doi. org/10.15359/rcv.33-2.1.

Financial Support: Pontificia Javeriana University funding the study through an internal research Grant. ID Project: 007609. 